\title{
RESENHA \\ Geografia e Conhecimentos Cartográficos \\ A cartografia no movimento de renovação da geografia brasileira \\ e a importância dos mapas
}

\author{
JOSÉ GILBERTO DE SOUZA E ÂNGELA MASSUMI KATUTA \\ Editora UNESP/FAPESP
}

\begin{abstract}
A renovação da geografia brasileira teve um de seus pecados numa certa ausência da renovação cartográfica. José Gilberto de Souza e Ângela Massumi Katuta tomam para objeto de seu livro este tema inexplicavelmente pouco explorado nas análises, já numerosas, da evolução da geografia brasileira destas últimas duas décadas.

No tratamento dado, os autores analisam o quadro dos contextos da geografia brasileira, da escola e da própria relação histórica da geografia com a cartografia. O capitalismo e a história das representações formam o quadro mais geral.

Pouco se tem feito de análise das relações do ensino da geografia com a escola. Mesmo no momento em que esta disciplina foi substituída pelos Estudos Sociais na escola brasileira, esta relação mereceu um estudo mais aprofundado. O que faz da geografia uma disciplina escolar? Que papel cumpre ela na escola? A geografia que se ensina vem para que finalidade?

E a cartografia? Que explicação se dá para a separação entre a cartografia e a geografia no contexto da modernidade avançada? É possível uma sem a outra? E possível o ensino da geografia sem o mapa?
\end{abstract}

São muitas as perguntas. Mas sejam quais forem as respostas, torna-se um incômodo a permanência da imagem do mapa como coisa do professor de geografia - da geografia escolar - na memória da sociedade, por séculos habituada a associar a cartografia a uma espécie de sinônimo de geografia.

Muito se debateu de temas de forte caráter cartográfico na renovação da geografia brasileira. Contraditoriamente, pouco se viu de uso de mapa entre os renovadores. O espaço, o território, a região, a rede, o lugar, a paisagem, todas são categorias geográficas que se fragilizam na ausência da linguagem e da técnica da representação cartográfica. Mesmo porque a cartografia não é mais que uma linguagem espacial, territorial, regional...

São problemas que Geografia e Conhecimentos Cartográficos levanta. Quando menos, suscitam ao debate do leitor.

Não menos interessante é a interpretação dos autores sobre o vínculo escola-capitalismo. Dois capítulos remetem a este tema em detalhes. Novas instigações ao leitor. Qual é o papel da escola no sistema do capitalismo? Orienta-o uma razão puramente ideológica, no sentido dos aparelhos ideológicos do Estado, que tanto se falou nos anos sessenta? Linha que, por sinal não é a dos autores. Ou, então, a função de formar mão-de-obra, na linha da LDB de Darcy Ribeiro, para o qual o papel da escola é o de preparar o cidadão ao novo mundo do trabalho. Um tema que os autores - o do trabalho - têm como uma das referências de toda a indagação, que remete ao próprio sentido da geografia, da história humana, da sociedade, para além do sentido da escola.

Leitura proveitosa, o livro é um texto saído das dissertações de mestrado dos autores, onde encontram-se depositados muitos dos bons trabalhos da lavra recente dos geógrafos brasileiros, a maioria dos quais, ficam desconhecidos na estante das bibliotecas dos nossos Programas de PósGraduação, à espera de uma acolhida como o que este livro de José Gilberto de Souza e Ângela Massumi Katuta com justiça mereceu. 